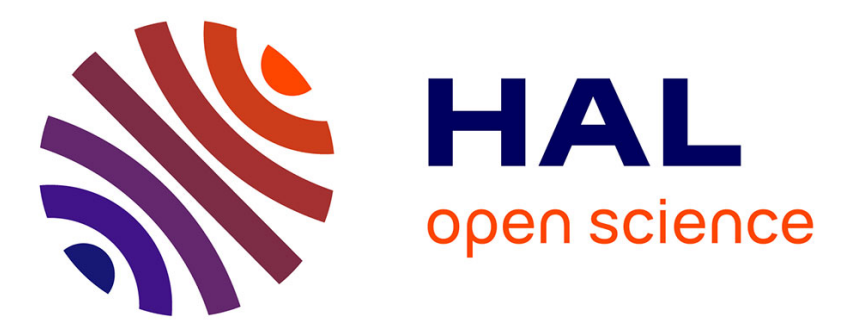

\title{
Predictors of Human Papilloma Virus (HPV) infection in Italian women
}

\author{
Maria Cecilia Cercato, Luciano Mariani, Amina Vocaturo, Angela Carrone, \\ Irene Terrenato, Giuseppina Morano, Maria Benevolo, Francesca Rollo, \\ Chiara Germelli, Francesca Paolini, et al.
}

\section{To cite this version:}

Maria Cecilia Cercato, Luciano Mariani, Amina Vocaturo, Angela Carrone, Irene Terrenato, et al.. Predictors of Human Papilloma Virus (HPV) infection in Italian women. Journal of Medical Virology, 2010, 82 (11), pp.1921. 10.1002/jmv.21887 . hal-00577347

\section{HAL Id: hal-00577347 https://hal.science/hal-00577347}

Submitted on 17 Mar 2011

HAL is a multi-disciplinary open access archive for the deposit and dissemination of scientific research documents, whether they are published or not. The documents may come from teaching and research institutions in France or abroad, or from public or private research centers.
L'archive ouverte pluridisciplinaire HAL, est destinée au dépôt et à la diffusion de documents scientifiques de niveau recherche, publiés ou non, émanant des établissements d'enseignement et de recherche français ou étrangers, des laboratoires publics ou privés. 


\section{Predictors of Human Papilloma Virus (HPV) infection in Italian women}

\begin{tabular}{|c|c|}
\hline Journal: & Journal of Medical Virology \\
\hline Manuscript ID: & JMV-10-1881.R1 \\
\hline Wiley - Manuscript type: & Research Article \\
\hline $\begin{array}{r}\text { Date Submitted by the } \\
\text { Author: }\end{array}$ & 01-Jun-2010 \\
\hline Complete List of Authors: & $\begin{array}{l}\text { Cercato, Maria Cecilia; Regina Elena National Cancer Institute, } \\
\text { Department of Epidemiology } \\
\text { Mariani, Luciano; Regina Elena National Cancer Institute, } \\
\text { Department of Gynaecologic Oncology } \\
\text { Vocaturo, Amina; Regina Elena National Cancer Institute, } \\
\text { Department of Pathology } \\
\text { Carrone, Angela; "Sapienza" University of Rome, Department of } \\
\text { Gynecology and Obstetrics } \\
\text { Terrenato, Irene; Regina Elena National Cancer Institute, } \\
\text { Department of Epidemiology } \\
\text { Morano, Giuseppina; "Sapienza" University of Rome, Department of } \\
\text { Gynecology and Obstetrics } \\
\text { Benevolo, Maria; Regina Elena National Cancer Institute, } \\
\text { Department of Pathology } \\
\text { Rollo, Francesca; Regina Elena National Cancer Institute, } \\
\text { Department of Pathology } \\
\text { Germelli, Chiara; Regina Elena National Cancer Institute, } \\
\text { Department of Gynaecologic Oncology } \\
\text { Paolini, Francesca; Regina Elena National Cancer Institute, } \\
\text { Laboratory of Virology } \\
\text { Venuti, Aldo; Regina Elena National Cancer Institute, Laboratory of } \\
\text { Virology }\end{array}$ \\
\hline Keywords: & HPV, Cervical cancer, risk factors, sexual behaviour, questionnaire \\
\hline
\end{tabular}

\section{S ScholaroNE" \\ Manuscript Central}




\title{
PREDICTORS OF HUMAN PAPILLOMA VIRUS (HPV) INFECTION IN ITALIAN WOMEN
}

\author{
M.C. Cercato ${ }^{*}$, L. Mariani ${ }^{\S}$, A. Vocaturo ${ }^{\#}$, A. Carrone ${ }^{+}$, I. Terrenato $^{*}$, G. Morano ${ }^{+}$, M.

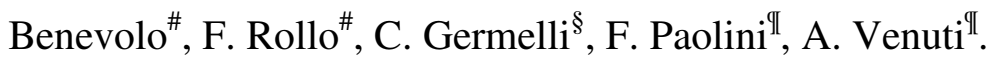

\section{Authors Affiliations:}

*Department of Epidemiology, "Regina Elena" National Cancer Institute", Via E. Chianesi 53, 00144 Rome, Italy.

${ }^{\S}$ Department of Gynaecologic Oncology, "Regina Elena” National Cancer Institute, Via E. Chianesi 53, 00144 Rome, Italy.

\# Department of Pathology, "Regina Elena” National Cancer Institute, Via E. Chianesi 53, 00144 Rome, Italy.

${ }^{+}$Department of Gynecology and Obstetrics "Sapienza" University of Rome, Viale del Policlinico 155, 00155 Rome, Italy.

"I Laboratory of Virology, "Regina Elena” National Cancer Institute, Via E. Chianesi 53, 00144 Rome, Italy.

Corresponding Author:

Cercato Maria Cecilia, Department of Epidemiology, "Regina Elena" National Cancer Institute, Via Elio Chianesi 53, 00144 Rome, ITALY. Tel.: +39-06-52666913; Fax: +39-06-52662732 (e-mail: cercato@ifo.it)

Shortened title: HPV infection risk factors

Grants : The Italian Ministry of Health partially funded the study. 


\begin{abstract}
Background: HPV infection is a "necessary cause" of cervical cancer and it is sexually transmitted. Due to upcoming mass vaccination investigation on risk factors for infection is the basis to implement prophylactic strategy even in older women.

Objective: The aim of the study was to evaluate predictors of high-risk HPV infection in adult women.
\end{abstract}

Methods: Between 2006 and 2008, one hundred women aged >18 years, with no previous treatment for cervical lesions, were screened for high-risk HPV infection in Rome, Italy. Risk factors for HPV infection were investigated through a questionnaire including: ethnicity, religion, education, marital status, sexual behaviour, gynaecological and obstetrical history, smoking and alcohol intake.

Results: Multivariate analysis identified the "never married-separated/divorced" status (OR: 3.38; 95\% CI: 1.14-10.12) as predictor of HPV infection, while having a higher age at the first sexual intercourse shows a protective effect (OR: 0.84 ; 95\% CI: 0.71 1.00). A trend for the association between the infection and having more than three lifetime partners was also observed (OR: 2,57; 95\% CI: 0.86-7.71). No significant association was found for other demographic characteristics investigated.

Conclusions: These findings provide a contribution in the knowledge of an adult population defining a "high risk" sexual behavioural profile and could be helpful to target prophylactic strategies in older woman.

\title{
Keywords
}

HPV, cervical cancer, epidemiology, risk factors, sexual behaviour, questionnaire. 


\section{INTRODUCTION}

Cervical cancer (CC) is associated with Human Papillomavirus (HPV) infection, which is transmitted during sexual intercourse [Walboomers et al., 1999; American Cancer Society, 2008]. CC is the second most common cancer in woman worldwide and is more frequent in socio-economically deprived regions where proper screening and/or vaccination programs are not easily available [World Health Organization, 2006; Almonte et al., 2008].

Over one hundred HPV genotypes have been identified and classified into lowrisk (LR) (e.g. type 6,11) and high-risk (HR) (e.g. type 16,18,31,33,45) groups, according to their potential oncogenic effects [Muñoz et al., 2006]. In the U.S.A., 75\% of women aged between 14 and 50 years become infected during their lives, but the great majority of HPV genital infections are transient and are cleared within 2 years by host immune response [World Health Organization, 2006]. Persistent infections with HR-HPV is involved in the pathogenesis of cervical intraepithelial neoplasia and in the progression to cervical cancer [Snijders et al., 2006].

HPV DNA prevalence varies by continent and by age: it is high (up to 30\%) in young women ( $<25$ years) all over the world except for Asia, decreasing in the middleage group, even though a second rise among in perimenopausal women has been recently observed [Almonte et al., 2008; Bosch et al., 2008; Smith et al., 2008].

Contracting HPV genital infection appears to be associated with increased sexual activity and thus with number of partners; other involved factors are age at the first sexual intercourse, marital status, cigarette smoking and contraceptives use [Vaccarella et al., 2006; Almonte et al., 2008; Herbert and Coffin, 2008]. However epidemiological studies investigating risk factors for HPV infection have not been entirely consistent, due to the differences in population characteristics (demographic 
growth rate, sexual habits, HPV prevalence) as well as to the potential misclassification involved in the assessment of sexual history [Schlecht et al., 2001; Schroder et al., 2003].

Despite increasing effort, the burden and natural history of HPV infection is not completely understood and the upcoming mass vaccination will certainly change HPV epidemiology. Therefore baseline (i.e. pre-vaccine) epidemiological investigations on risk factors for infection should be encouraged to provide the basis to implement prophylactic strategies.

The aim of the present study was to investigate predictors of HR-HPV infection in women referred as outpatients to the "Regina Elena" National Cancer Institute and to the University "La Sapienza” in Rome, Italy, for HPV DNA detection and cervical cancer prevention.

\section{MATERIALS AND METHODS}

$\underline{\text { Population and study design }}$

This study was part of a cooperative project conducted from April 2006 to December 2008, supported by the Italian Ministry of Health and coordinated by the "Regina Elena" National Cancer Institute. The study population were women who consecutively attended the Department of Gynaecologic Oncology of the "Regina Elena" National Cancer Institute and of the University "La Sapienza" of Rome, as outpatients for HPV DNA detection and cervical cancer prevention. Exclusion criteria were: age $<18$ years, positive history for cancer, previous surgical treatment for cervical lesions, presence of immunological disorders, pregnancy or cognitive impairment. Eligible patients were asked to participate and a written informed consent obtained. The study was approved by the Local Medical Ethical Committee. 
At enrolment a baseline questionnaire investigating common risk factors for HPV infection and for cervical cancer was given by the physician just before the clinical examination. A gynaecologist collected clinical data and during the scheduled clinical procedures collected cervicovaginal specimens for HPV DNA analysis to be delivered to the Department of Pathology.

\section{Questionnaire}

The questionnaire, to be filled in by the patient, consisted of multiple choice questions addressing: ethnicity, religion, educational level, marital status, gynaecologic and obstetric history, sexual behaviour (age at first intercourse, lifetime number of partners, frequency of intercourse), contraceptive use, alcohol use and smoking. Knowledge about Pap test and frequency of testing was also investigated.

\section{HPV DNA Detection and Genotyping}

Cervico-vaginal specimens were collected by cytobrush (Cytyc, Rome, Italy) and Ayre spatula (Cytyc), in $20 \mathrm{~mL}$ of PreservCyt solution (Cytyc), stored at $4^{\circ} \mathrm{C}$ until the use.

HR HPV test was performed according to scientific evidence by means of the HC2 technique (Qiagen, Milan, Italy), a semi-quantitative signal-amplified hybridization assay for the chemiluminescent detection of the 13 most common HR HPV types (genotypes: 16, 18, 31, 33, 35, 39, 45, 51, 52, 56, 58, 59 and 68), as described by the manufacturer [Leinonen et al., 2009]. Before the HC2 testing, $4 \mathrm{ml}$ of PreservCyt solution were processed by means of the HC2 Sample Conversion Kit (Qiagen). The positive cut-off $(\mathrm{CO})$ value was considered the average of the positive control samples. The results were considered positive when the ratio between the specimen's light emission units (RLU) and the chosen positive CO (RLU/CO) was 1 or greater.

HPV DNA genotyping was carried out by using Linear Array HPV Genotyping Test (LA Roche Molecular System, Rome, Italy). $250 \mu 1$ of PreservCyt sample were taken 
for DNA extraction, as described by the manufacturer. The assay involves the amplification of a 450 bp amplicon, generated by a consensus PGMY primer set, targeting the conserved L1 region [Gravitt et al., 2000; Coutlée et al., 2002]. The detection of amplified products was achieved by the hybridization to a nylon strip, containing two levels of $\beta$-globin control probes and 37 LR and HR anogenital HPV types probes (types $6,11,16,18,26,31,33,35,39,40,42,45,51,52,53,54,55,56$, $58,59,61,62,64,66,67,68,69,70,71,72,73,81,82,83,84$, IS39 and CP6180).

\section{$\underline{\text { Statistical analysis }}$}

For the analysis the patients were categorized as "HPV-positive" when at least one of the two basal HPV DNA tests were positive for high risk genotypes and as "HPVnegative" when it tested negative to both tests.

Descriptive statistics were computed for all variables. Continuous data were reported as the mean and standard deviation or the median and range; categorical data were represented by frequencies and percentage values. The Student's T-test was used to compare continuous variables; the Pearson's Chi-Squared and Fisher's Exact test, when appropriate, were used to detect potential differences between categorical variables. Cohen's Kappa and its relative 95\% Confident Interval (95\% CI) was used to assess the concordance the between HC2 and Linear Array HPV Genotyping Test in detecting the HPV status. P-values less than 0.05 were considered statistically significant.

Odds ratios (ORs) and their relative 95\% CIs were computed through univariate and multivariate logistic regression models in order to evaluate the association between HPV infection and socio-demographic and behavioural variables. Data of some variables were grouped due to the small number. "Primary" and "secondary school" educational levels were grouped together. Furthermore, "marital status" was divided into two categories "never married-separated/divorced" and "married-living together- 


\section{RESULTS}

Ninety-four out of the 100 consecutive eligible women submitted to the HPV DNA detection and genotyping tests agreed to complete the questionnaire.

According to the results of detection and genotyping HPV DNA tests 54 (57\%) women were classified as "HR-HPV-positive" and 40 (43\%) as "HPV-negative". The agreement between the two tests was 91\% (Cohen's K: $0.8395 \%$ CI[0.63 -1.00] ).

Overall, twenty-five different genotypes were identified: the most common high-risk types were $16(28 \%), 31(16 \%), 51$ and $52(14 \%)$ (Figure 1). No single low-risk infection was found. Multiple HPV types were detected in $26(50 \%)$ out of the 52 positive women at the Linear Array HPV Genotyping Test. Co-infection by two viruses were found in $25 \%$ of the positive cases, by three viruses in $15 \%$ and by more than three viruses in $10 \%$. Co-infection by three or more genotypes were more frequent in young (>35 years) woman (33\% vs $9 \%)$. 
Table I shows the characteristics of the population. All except one were Caucasian and the great majority (90\%) belonged to the Christian faith (data not shown). The "positive" women were slightly younger but the mean age values did not differ significantly in the two groups. The "positive" women were more frequently "never married-separated/divorced", reported a lower age at their first sexual intercourse (FSI) (17,9 vs 20.3 years), a higher number of lifetime partners (5.3 vs 3.0), smoking habits and alcohol consumption. No differences in educational level, number of pregnancies and of childbirths, frequency of intercourse, and use of estroprogestinic as well as condoms were observed. Almost all women reported to have knowledge of the Pap test and to undergo it regularly or occasionally.

At univariate analysis marital status, age at the FSI, lifetime numbers of sexual partners, past or current smoking habits, years of smoking, number of cigarettes, and regular use of alcohol were all factors predicting HPV infection (Tab.II). Multivariate analysis confirmed that the "never married-separated/divorced" status and a lower age at the first sexual intercourse were independent factors predicting HR-HPV infection (Tab.II). A trend for the association between the infection and having more than three lifetimes partners was also observed. No association was found for other variables included in the logistic regression model.

\section{DISCUSSION}

Cervical cancer is the second most common cancer in women worldwide and the estimate of the attributable fraction due to HPV infection range from $90 \%$ to $98 \%$ [Bosch and de Sanjosé, 2003]. HPV 16 and 18 are the most frequent types associated with $\mathrm{CC}$ and two prophylactic vaccines against these high-risk variants have been 
recently introduced in several countries mainly in young women (up to 26 years)[Ault and the FUTURE II Study Group, 2007; Harper and Paavonen, 2008].

This study describes the predictors of HR-HPV infection in a sample of Italian women. The results highlight the behavioural characteristics that identify a "high-risk" profile for HPV infection, providing useful information to widen future prophylactic strategies also in older age-classes.

The high compliance obtained (94\%) confirmed the practicable features of the questionnaire employed and showed a positive attitude towards cervical cancer prevention of these women who, once informed about the aim of the study, agreed to disclose information on their sexual behaviour.

The results of the multivariate analysis showed that having a "never marriedseparated/divorced" status and an early age at the FSI are independent risk factors for HR-HPV infection. A trend, although not significant probably for the small size of the population, was also observed for having more than three lifetime partners. These findings are in agreement with previous studies showing that having a "never married" or a "separated/divorced" status, an early age at the FSI or a higher "sexual age" (i.e. years of being sexually active) are all factors associated with HPV infection [Almonte et al., 2008; Sellors et al., 2000; Lenselink et al., 2008; Tonon et al., 1999]. According to other authors age at the FSI is more likely to be a predictor of the total number of partners in a lifetime than a factor independently associated with the infection [Hildesheim et al., 2001; Burchell et al., 2006].

Sexual activity with changing partners represents an additional well-known predictor of infection [Almonte et al., 2008; Herbert and Coffin, 2008; Vaccarella et al., 2006; Chan et al., 2009; Sellors et al., 2000; Sellors et al., 2003; Lenselink et al., 2008; Shields et al., 2004; Venuti et al., 1994]. A pooled analysis of the IARC HPV surveys of 
11,337 women of nine countries (including areas Latino America, South-Eastern Asia, Spain and Africa) reported a significant increased risk of HPV infection (any type) for women with two or more lifetime partners vs one (OR: 1.86; 95\%CI: 1.63-2.11) [Vaccarella et al., 2006]. In several case-control and cross sectional studies conducted in countries at different HPV prevalence the lifetime number and the number of sexual partners in the last 6-12 months were strongly associated with the presence of the infection [Almonte et al., 2008; Lenselink et al., 2008; Winer et al., 2003].

In this study the multivariate analysis showed no association between the risk of infection and the use of oral contraceptives, the use of condom, smoking and alcohol intake. The findings are consistent with the results of other studies, however no conclusive data are available [Lenselink et al., 2008; Sellors et al., 2003; Sellors et al., 2000; Winer et al., 2003]. In fact, the protective effect of a condom against HPV infection is not well established and does not seem to be as strong as for other sexual transmitted infections because of its transmission by skin-to-skin contact [Vaccarella et al., 2006; Burchell et al., 2006]. Data on the role of smoking is still debated and some studies show a positive association with current or past smoking habits [Sellors et al., 2000; Winer et al., 2003; Chan et al., 2009]. Smoking has been independently associated with an increased risk of cervical cancer and therefore has an acting role as a HPV co-factor in the cancerogenesis process [International Collaboration of Epidemiological studies of Cervical Cancer, 2007].

The study was not aimed to assess the prevalence of HPV infection. The high prevalence of the HR-HPV DNA infection observed in this population is probably due to the sample selection among patients referred by their general practitioners to two qualified Institutions for Research for HPV detection and cervical cancer screening, and could represent a limitation of the study. Other limitations are the small size of the 
sample that does not allow to investigate the role of a specific HR-HPV type, and, as highlighted by other authors, the potential misclassification involved in reporting sexual history due to the recall biases or to intentional under-reported number of partners [Schroder et al., 2003; Schlecht et al., 2001]. Finally, previous infections in HPV negative patients were not assessed by serologic markers taking into account the low sensibility of the test as well as the scant relevance of the transient infections in the carcinogenesis [Snijders et al., 2006; Schiffman and Castle, 2003]

Epidemiology of HPV infection is going to chance because of upcoming mass vaccination. HPV vaccine trials have established that both vaccines (the bivalent against $16,18$ and the quadrivalent against $16,18,6,11)$ produce a potent immunological response and are associated with an efficacy rate close to $100 \%$ for at least 5 years in naïve women [Villa et al., 2005; Villa et al., 2006; Harper et al., 2004; Harper et al., 2006; Ault and the FUTURE II Study Group, 2007; Paavonen et al., 2009]. National regulatory agencies (i.e. Food and Drug Administration, European Medicines Agency) have approved the two commercial products $\left(\right.$ Gardasil $^{\mathrm{TM}}$ and Cervarix ${ }^{\mathrm{TM}}$ ) in most countries for use in young women (up to 26 years). Furthermore, because of the evidence of immunobridging also in women up to the age of 55 years, in selected regions there are approvals for women aged >26 years [Harper and Paavonen, 2008; Schwarz et al., 2009; Castellsagué et al., 2009].

Taking into account the safety and efficacy data available, increasing interventions to immunize women of different ages are expected.

\section{CONCLUSIONS}

Prevalence of HR-HPV infection is high in this selected population and is mainly associated to sexual behaviour. These findings contribute to the knowledge of an 
adult population in defining a "high risk" behavioural profile and could be helpful to target prophylactic strategies in older woman.

\section{Conflict of interest statement}

The authors have no conflict of interest to disclose.

\section{AKNOWLEDGMENTS}

The authors thank the Italian Ministry of Health that partially funded the study and the Lega Italiana Lotta Tumori (LILT). 


\section{REFERENCES}

Almonte M, Albero G, Molano M, Carcamo C, García PJ, Pérez G. 2008. Risk factors for human papillomavirus exposure and co-factors for cervical cancer in Latin America and the Caribbean. Vaccine 26:L16-36.

American Cancer Society. 2008. Detailed guide: cervical cancer. What are the risk factors for cervical cancer? American Cancer Society Web site. Available at: http://www.cancer.org/docroot/CRI/content/CRI_2_4_2X_What_are_the_risk_factors_f or_cervical_cancer_8.asp.(last accessed: November 15, 2009).

Ault KA, The Future II Study Group. 2007. Effect of prophylactic human papillomavirus L1 virus-like-particle vaccine on risk of cervical intraepithelial neoplasia grade 2, grade 3, and adenocarcinoma in situ: a combined analysis of four randomized clinical trial. Lancet 369:1861-1868.

Bosch FX, de Sanjosé S. 2003. Chapter 1 : Human papillomavirus and cervical cancerburden and assessment of causality. J Natl Cancer Inst Monogr 31:3-13.

Bosch FX, Burchell AN, Schiffman M, Giuliano AR, de Sanjosè S, Bruni L, TortoleroLuna G, Kruger Kjaer S, Muñoz N. 2008. Epidemiology and natural history of Human Papilloma Virus infections and type-specific implications in cervical neoplasia. Vaccine 26:K1-K16.

Burchell AN, Winer RL, de Sanjose S, Franco EL. 2006. Chapter 6: Epidemiology and transmission dynamics of genital HPV infection. Vaccine 24:S52-S61. 
Castellsagué X, Schneider A, Kaufmann AM, Bosch FX. 2009. HPV vaccination against cervical cancer in women above 25 years of age: key considerations and current perspectives.Gynecol Oncol 115:S15-S23.

Chan PK, Ho WC, Wong MC, Chang AR, Chor JS, Yu MY. 2009. Epidemiologic risk profile of infection with different groups of human papillomaviruses. J Med Virol 81: $1635-1644$.

Coutlée F, Gravitt P, Kornegay J, Hankins C, Richardson H, Lapointe N, Voyer H, Franco E. 2002. Use of PGMY primers in L1 consensus PCR improves detection of human papillomavirus DNA in genital samples. J Clin Microbiol 3:902-7.

P.Contoyannis, A. M Jones. 2004. Socio-Economic Status, Health and Lifestyle. Journal of Health Economics 23:965-995.

Gravitt PE, Peyton CL, Alessi TQ, Wheeler CM, Coutlée F, Hildesheim A, Schiffman MH, Scott DR, Apple RJ. 2000. Improved amplification of genital human papillomaviruses. J Clin Microbiol 38:357-61.

Harper DM, Franco EL, Wheeler C, Ferris DG, Jenkins D, Schuind A, Zahaf T, Innis B, Naud P, De Carvalho NS, Roteli-Martins CM, Teixeira J, Blatter MM, Korn AP, Quint W, Dubin G; GlaxoSmithKline HPV Vaccine Study Group. 2004. Efficacy of a bivalent L1 virus-like particle vaccine in prevention of infection with human papillomavirus types 16 and 18 in young women: a randomized controlled trial. Lancet 364:1757-1765. 
Harper DM, Franco EL, Wheeler CM, Moscicki AB, Romanowski B, Roteli-Martins CM, Jenkins D, Schuind A, Costa Clemens SA, Dubin G; HPV Vaccine Study group. 2006. Sustained efficacy up to 4.5 years of a bivalent L1 virus-like particle vaccine against human papillomavirus types 16 and 18: follow-up from a randomized control trial. Lancet 367:1247-1255.

Harper MD, Paavonen J. 2008. Age for HPV vaccination. Vaccine 26:A7-A11.

Herbert J, Coffin J. 2008. Reducing patient risk for human papillomavirus infection and cervical cancer. J Am Osteopath Assoc 108:65-70.

Hildesheim A, Herrero R, Castle PE,Wacholder S, Bratti MC, Sherman ME, Lorincz AT, Burk RD, Morales J, Rodriguez AC, Helgesen K, Alfaro M, Hutchinson M, Balmaceda I, Greenberg M, Schiffman M. 2001. HPV co-factors related to the development of cervical cancer: results from a population-based study in Costa Rica. $\mathrm{Br}$ J Cancer 84:1219-1226.

International Collaboration of Epidemiological Studies of Cervical Cancer, Appleby P, Beral V, Berrington de Gonzalez A, Colin D, Franceschi S, Goodhill A, Green J, Peto J, Plummer M, Sweetland S. 2007. Cervical cancer and hormonal contraceptives: collaborative reanalysis of individual data for 16,573 women with cervical cancer and 35,509 women without cervical cancer from 24 epidemiological studies. Lancet 370: $1609-1621$. 
Leinonen M, Nieminen P, Kotaniemi-Talonen L, Malila N, Tarkkanen J, Laurila P, Anttila A. 2009. Age-specific evaluation of primary human papillomavirus screening vs conventional cytology in a randomized setting. J Natl Cancer Inst 101:1612-1623.

Lenselink CH, Melchers WJ, Quint WG, Hoebers AM, Hendriks JC, Massuger LF, Bekkers RL. 2008. Sexual behaviour and HPV infections in 18 to 29 year old women in the pre-vaccine era in the Netherlands. PLoS One 3:e3743.

Muñoz N, Castellsagué X, berrington de González, Gissmann L. 2006. Chapter 1: HPV in the etiology of human cancer. Vaccine 24 (Suppl 3):1-10.

Paavonen J, Naud P, Salmerón J, Wheeler CM, Chow SN, Apter D, Kitchener H, Castellsague X, Teixeira JC, Skinner SR, Hedrick J, Jaisamrarn U, Limson G, Garland S, Szarewski A, Romanowski B, Aoki FY, Schwarz TF, Poppe WA, Bosch FX, Jenkins D, Hardt K, Zahaf T, Descamps D, Struyf F, Lehtinen M, Dubin G; HPV PATRICIA Study Group, Greenacre M. 2009. Efficacy of human papillomavirus (HP oncogenic HPV types (PATRICIA): final analysis of a double-blind, randomised study in young women. Lancet 374:301-314.

Schiffman MH, Castle P. 2003. Epidemiologic studies of a necessary causal risk factor: human papillomavirus infection and cervical neoplasia. J Natl Cancer Inst 95 (6):E2.

Schlecht NF, Franco EL, Rohan TE, Kjaer SK, Schiffman MH, Moscicki AB, Duffy SW; Marsh International Collaborative Group. 2001. Repeatability of sexual history in 
longitudinal studies on HPV infection and cervical neoplasia: determinants of reporting error at follow-up interviews. J Epidemiol Biostat 6:393-407.

Schroder KE, Carey MP, Vanable PA. 2003. Methodological challenges in research on sexual risk behavior: II. Accuracy of self-reports. Ann Behav Med 26:104-123.

Schwarz TF, Spaczynski M, Schneider A, Wysocki J, Galaj A, Perona P, Poncelet S, Zahaf T, Hardt K, Descamps D, Dubin G; HPV Study Group for Adult Women. 2009. Immunogenicity and tolerability of an HPV-16/18 AS04-adjuvanted prophylactic cervical cancer vaccine in women aged 15-55 years. Vaccine 27:581-587.

Sellors JW, Mahony JB, Kaczorowski J, Lytwyn A, Bangura H, Chong S, Lorincz A, Dalby DM, Janjusevic V, Keller JL. 2000. Prevalence and predictors of human papillomavirus infection in women in Ontario, Canada. Survey of HPV in Ontario Women (SHOW) Group. CMAJ 163:503-508.

Sellors JW, Karwalajtys TL, Kaczorowski J, Mahony JB, Lytwyn A, Chong S, Sparrow J, Lorincz A; Survey of HPV in Ontario Women Group. 2003. Incidence, clearance and predictors of human papillomavirus infection in women. CMAJ 168:421-425.

Shields TS, Brinton LA, Burk RD, Wang SS, Weinstein SJ, Ziegler RG, Studentsov YY, McAdams M, Schiffman M. 2004. A case-control study of risk factors for invasive cervical cancer among U.S. women exposed to oncogenic types of human papillomavirus. Cancer Epidemiol Biomarkers Prev 13:1574-1582. 
Smith JS, Melendy A, Rana RK, Pimenta JM. 2008. Age-specific prevalence of infection with human papillomavirus in females: a global review. J Adolesc Health. 43:S5-25, S25. e1-41.

Snijders PJ, Steenbergen RD, Heideman DA, Meijer CJ. 2006. HPV-mediated cervical carcinogenesis: concepts and clinical implications. J Pathol 208:152-164.

Solomon D, Davey D, Kurman R, Moriarty A, O'Connor D, Prey M, Raab S, Sherman M, Wilbur D, Wright T Jr, Young N; Forum Group Members; Bethesda 2001 Workshop. 2002. The 2001 Bethesda System: terminology for reporting results of cervical cytology. JAMA 287:2114-2119.

Tonon SA, Picconi MA, Zinovich JB, Liotta DJ, Bos PD, Galuppo JA, Alonio LV, Ferreras JA, Teyssié AR. 1999. Human Papillomavirus cervical infection and associated risk factors in a region of Argentina with a high incidence of cervical carcinoma. Infectious Diseases in Obstetrics and Gynecology 7:237-243.

Vaccarella S, Franceschi S, Herrero R, Muñoz N, Snijders PJ, Clifford GM, Smith JS, Lazcano-Ponce E, Sukvirach S, Shin HR, de Sanjosé S, Molano M, Matos E, Ferreccio C, Anh PT, Thomas JO, Meijer CJ; IARC HPV Prevalence Surveys Study Group. 2006. Sexual behavior, condom use, and human papillomavirus: pooled analysis of the IARC human papillomavirus prevalence surveys. Cancer Epidemiol Biomarkers Prev 15:326333. 
Venuti A, Badaracco G, Sedati A, Carbini R, Marcante ML. 1994. Determinants of human papillomavirus types 16 and 18 infections in the lower femal genital tract in an Italian population. Eur J Gynaec Oncol 15:205-210.

Villa LL, Costa RL, Petta CA, Andrade RP, Ault KA, Giuliano AR, Wheeler CM, Koutsky LA, Malm C, Lehtinen M, Skjeldestad FE, Olsson SE, Steinwall M, Brown DR, Kurman RJ, Ronnett BM, Stoler MH, Ferenczy A, Harper DM, Tamms GM, Yu J,Lupinacci L, Railkar R, Taddeo FJ, Jansen KU, Esser MT, Sings HL, Saah AJ, Barr E. 2005. Prophylactic quadrivalent human papillomavirus (types 6, 11, 16, and 18) L1 virus-like particle vaccine in young women: a randomised double-blind placebocontrolled multicentre phase II efficacy trial. Lancet Oncol. 6:271-278.

Villa LL, Costa RL, Petta CA, Andrade RP, Paavonen J, Iversen OE, Olsson SE, Høye J, Steinwall M, Riis-Johannessen G, Andersson-Ellstrom A, Elfgren K, Krogh G, Lehtinen M, Malm C, Tamms GM, Giacoletti K, Lupinacci L, Railkar R, Taddeo FJ, Bryan J, Esser MT, Sings HL, Saah AJ, Barr E. 2006. High sustained efficacy of a prophylactic quadrivalent human papillomavirus types 6/11/16/18 L1 virus-like particle vaccine through 5 years of follow-up. Br J Cancer 95:1459-1466.

Walboomers JM, Jacobs MV, Manos MM, Bosch FX, Kummer JA, Shah KV, Snijders PJ, Peto J, Meijer CJ, Muñoz N. 1999. Human papillomavirus is a necessary cause of invasive cervical cancer worldwide. J Pathol 189:12-9.

Winer RL, Lee SK, Hughes JP, Adam DE, Kiviat NB, Koutsky LA. 2003. Genital human papillomavirus infection: incidence and risk factors in a cohort of female 
university students. Am J Epidemiol 157: 218-26. Erratum in: Am J Epidemiol 2003 157: 858 .

World Health Organization, 2006. Initiative for vaccine research (IVR): human papillomavirus. World Health Organization Web site. Available at: http://www.who.int/vaccine_research/diseases/ viral_cancers/en/index3.html. (last accessed: October 22, 2009). 
Table I. Characteristics of the 94 patients according to HPV DNA tests results.

\begin{tabular}{|c|c|c|c|}
\hline Variable & $\begin{array}{c}\text { HR-Positive } \\
\mathrm{N}^{*}(\%)\end{array}$ & $\begin{array}{c}\text { Negative } \\
\mathrm{N}^{*}(\%)\end{array}$ & p-value \\
\hline $\mathbf{N}$ of patients & $54(57)$ & $40(43)$ & \\
\hline \multicolumn{4}{|l|}{ Age } \\
\hline mean $(\mathrm{sd})$ & $35(10.2)$ & $39(11.2)$ & 0.112 \\
\hline Education & & & 0.755 \\
\hline Primary-Secondary school & $15(60)$ & $10(40)$ & \\
\hline High school & $27(54)$ & $23(46)$ & \\
\hline University & $12(63)$ & $7(37)$ & \\
\hline Marital status & & & $<0.0001$ \\
\hline Married-Living togheter-Widow & $13(33)$ & $26(67)$ & \\
\hline Never married-Separeted/Divorced & $40(74)$ & $14(26)$ & \\
\hline Age at first sexual intercourse & & & 0.003 \\
\hline mean (sd) & $17.9(2.4)$ & $20.3(4.9)$ & \\
\hline Number of partners & & & 0.004 \\
\hline mean (sd) & $5.3(3.8)$ & $3.0(3.3)$ & \\
\hline Number of pregnancies & & & 0.209 \\
\hline mean $(\mathrm{sd})$ & $1(1.5)$ & $1.3(1.3)$ & \\
\hline Number of childbirth & & & 0.080 \\
\hline media $(\mathrm{sd})$ & $0.6(0.8)$ & $1(1.2)$ & \\
\hline Estroprogestinic contraceptive use & & & 0.128 \\
\hline Yes & $33(63)$ & $19(37)$ & \\
\hline No & $18(47)$ & $20(53)$ & \\
\hline Condom contraceptive use & & & 0.172 \\
\hline Yes & $14(70)$ & $6(30)$ & \\
\hline No & $37(53)$ & $33(47)$ & \\
\hline $\mathbf{N}^{\circ}$ sexual intercourse & ( & & 0.105 \\
\hline Mean (sd) per months & $7.9(6.5)$ & $5.7(5.7)$ & \\
\hline Smoking & & & 0.043 \\
\hline Yes & $33(67)$ & $16(33)$ & \\
\hline No & $21(47)$ & $24(53)$ & \\
\hline Age at first cigarette & & & 0.072 \\
\hline media (sd) & $16.8(2.8)$ & $18.5(3.0)$ & \\
\hline Years of smoking & & & 0.008 \\
\hline media (sd) & $9.7(11.1)$ & $4.3(7.2)$ & \\
\hline Number of smoked cigarettes & & & 0.014 \\
\hline media (sd) & $7.3(7.7)$ & $3.6(6.1)$ & \\
\hline Alcohol consumption & & & 0.026 \\
\hline Yes (regular and occasional drinkers) & $23(26)$ & $8(74)$ & \\
\hline No & $31(50)$ & $31(50)$ & \\
\hline Pap Test knowledge & & & 0.178 \\
\hline Yes & $54(59)$ & $38(41)$ & \\
\hline No & $0(0)$ & $2(100)$ & \\
\hline Pap test frequency & & & 0.930 \\
\hline Every $1-2$ years & $44(58)$ & $32(42)$ & \\
\hline Occasionally & $7(58)$ & $5(42)$ & \\
\hline Never & $3(50)$ & $3(50)$ & \\
\hline
\end{tabular}

* the sum may not add to the total because of missing values. 
Table II. Predictors of HR-HPV infection in women: univariate and multivariate logistic regression analysis.

\section{Variables}

9 Age*

1 Education

12 rimary-Secondary

13igh School

14 University

15 Marital Status

1 Married/Living together/Widow

1\$ever married-Separated/Divorced

19 Age at first sexual intercourse*

2 Number of partners

2 z 3

23,3

25 moking

$26 \mathrm{No}$

$2 x_{\text {es }}$

28: Ilchol consumption

$3 \mathrm{No}^{\mathrm{No}}$

3 Yes (regular and occasional drinkers)

3 Estroprogestinic contraceptive use $34^{3} \mathrm{Yes}$

35ेo

3condom use

37

38

3 No

40

41

42

43

44

45

46

47

48

49

50

51

52

53

54

55

56

57

58

59

60

* considered as continuos variables

\begin{tabular}{|c|c|c|c|c|c|}
\hline Univariate $\mathbf{O R}$ & $95 \% \mathrm{CI}$ & p-value & Multivariate OR & $95 \% \mathrm{CI}$ & p-value \\
\hline 0,97 & $0,93-1,00$ & 0,116 & & & \\
\hline 0,87 & $0,26-2,99$ & 0,831 & & & \\
\hline 0,69 & $0,23-2,03$ & 0,494 & & & \\
\hline 1,00 & - & - & & & \\
\hline 1,00 & - & $<0,0001$ & 1,00 & - & 0,029 \\
\hline 5,71 & $2,32-14,08$ & & 3,38 & $1,14-10,12$ & \\
\hline 0,82 & $0,71-0,95$ & $\begin{array}{c}0,007 \\
<0,0001\end{array}$ & 0,84 & $0,71-1,00$ & 0,055 \\
\hline 1,00 & - & & 1,00 & - & 0,092 \\
\hline 5,32 & $2,09-13,95$ & & 2,57 & $0,86-7,71$ & \\
\hline 1,00 & - & 0,044 & 1,00 & - & 0,131 \\
\hline 2,36 & $1,02-5,44$ & 0,029 & 2,24 & $0,79-6,39$ & \\
\hline 1,00 & - & & 1,00 & - & 0,117 \\
\hline 2,88 & $1,12-7,41$ & 0,13 & 2,56 & $0,79-8,33$ & \\
\hline $\begin{array}{l}1,93 \\
1,00\end{array}$ & $\begin{array}{c}0,82-4,52 \\
-\end{array}$ & & & & \\
\hline $\begin{array}{l}0,48 \\
1,00\end{array}$ & $\begin{array}{c}0,17-1,39 \\
-\end{array}$ & 0,178 & & & \\
\hline
\end{tabular}


1

2

3

4

5

6

7

8

9

10

11

12

13

14

15

16

17

18

19

20

21

22

23

24

25

26

27

28

29

30

31

32

33

34

35

36

37

38

39

40

41

42

43

44

45

46

47

48

49

50

51

52

53

54

55

56

57

58

59

60

Fig. 1. Distribution of HPV genotypes detected by Linear Array Genotyping Test in the Italian women.

* CP6108

$8 \times 3 \mathrm{~mm}(600 \times 600$ DPI $)$ 